\title{
Effect of Lumbar Stabilization Exercises on Stable versus Unstable Surface on Pain and Function in Mechanical Low Back Pain - An Evidence Based Study
}

\author{
Rima Paraskumar Pandya ${ }^{1}$, Yagna Unmesh Shukla ${ }^{2}$ \\ ${ }^{1}$ M.P.T. (Orthopedics), ${ }^{2}$ M.P.T. (Musculoskeletal), Ph.D. Senior Lecturer, \\ Government Spine Institute and Government Physiotherapy College, Civil Hospital, Asarwa, Ahmedabad \\ Corresponding Author: Rima Paraskumar Pandya
}

\begin{abstract}
Background: Low back pain is the most common complaint all over the world. Lumbar instability is an important causative factor for low back pain. Lumbar stabilization exercises are helpful in reducing and preventing its recurrence.
\end{abstract}

Purpose: To study the evidences regarding effect of lumbar stabilization exercises on stable versus unstable surface on pain and function in mechanical low back pain.

Methodology: The study was conducted according to Preferred Reporting Items for systematic reviews and meta-analysis guidelines. Evidences selected since year 2010February 2020 from PubMed, Google Scholar, Physiotherapy Evidence Database (PEDro), Research Gate, Science Direct and Cumulative Index of Nursing and Allied Health Literature. Key words used were: Lumbar stabilization exercise, Core stability exercise, Pain and Function. Analysis was done using 2 scales: PEDro scale and Centre for Evidence-Based Medicine Levels of Evidence Scale. Total 202 articles were found, out of which 22 articles were relevant and from those 17 articles were included in the study and other articles were excluded as per eligibility criteria.

Results: 11 studies were shown that core stability exercise is effective treatment for reducing pain and improving disability. (Level of evidence-1a,1b,2b). 2 studies were showed that motor control exercise was more effective than core stability exercise. (Level of evidence1b). 4 studies shown that lumbar stabilization exercise performed on unstable surfaces showed significant improvement in back pain and disability (Level of evidence-1b, 2b).

Conclusion: Lumbar stabilization exercise performed on unstable surface provides significant benefit in reducing pain and improving function in patients with mechanical low back pain.

Key words: Lumbar stabilization exercise, Core stability exercise, Pain and Function Low Back Pain.

\section{INTRODUCTION}

Low back pain (LBP) is defined as "Pain and discomfort, localised below the costal margin and above the inferior gluteal folds, with or without leg pain". [1]

The most common form of low back pain is the one that is called "Nonspecific low back pain" and is defined as "Low back pain not attributed to recognizable, known specific pathology". [2] Nonspecific Low Back Pain also described as "simple backache", the everyday bodily symptom that most adults get at some time in their life. This is common "Mechanical" back pain of musculoskeletal origin in which symptoms vary with physical activity. Clinically, simple backache commonly is related to physical "strains", although these often are normal daily activities, and perhaps in reality, it usually develops spontaneously. ${ }^{[3]}$ Lumbar instability is an 
important cause of low back pain and that can lead to substantial disability. ${ }^{[4]}$ Segmental instability is defined by Panjabi ${ }^{[5]}$ as "a significant decrease in the capacity of the stabilizing system of the spine to maintain the intervertebral neutral zones within the physiological limits so that there is no neurological dysfunction, no major deformity, and no incapacitating pain".

The stabilizing exercises focus on the re-education of a precise co-contraction pattern of local muscles of the spine. ${ }^{[6]}$ Studies have identified core muscle activation in low back pain can decrease pain and improve function, but there is limited research on effect of Lumbar stabilization exercise on stable versus unstable surface in back pain and function. Hence, there is need to conduct the study. Hence purpose of the present study is to find the evidences regarding effect of lumbar stabilization exercises on stable versus unstable surface on pain and function in mechanical low back pain.

\section{METHODOLOGY}

Study Type: This is an Evidence Based Study was conducted according to Prefferred Reporting Items for Systematic Reviews and Meta-analysis (PRISMA) guidelines (Figure 1).

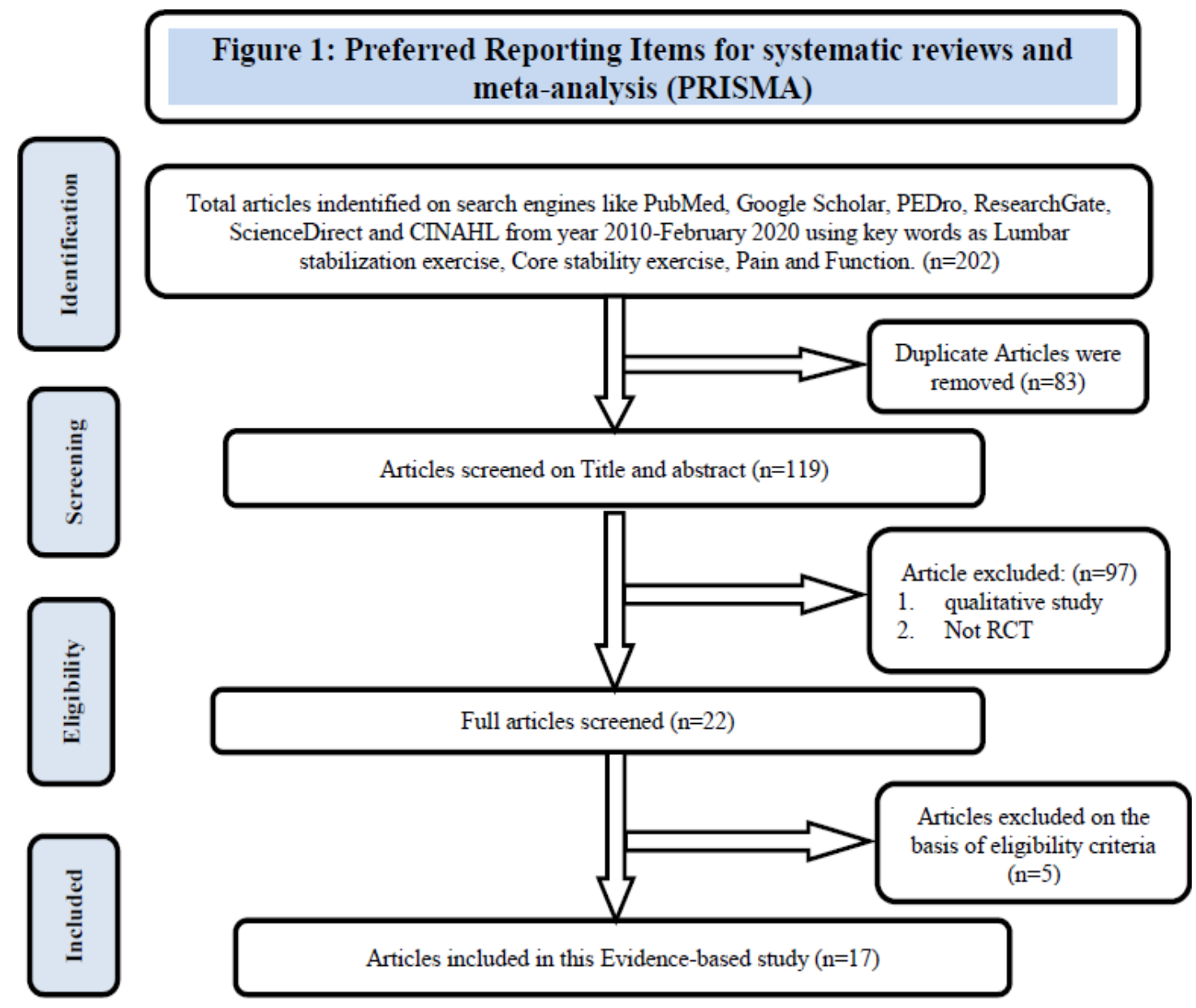

Search strategy: The search engines used for the finding out appropriate articles were: Google Scholar, PubMed, PEDro, Science Direct, Research Gate, CINAHL.
Key words used for the search were: Lumbar stabilization exercise, Core stability exercise, Low back pain, Pain and function. Eligibility criteria: Articles were selected from last 11 years (2010-February 2020). Total 202 articles were found, out of which 
Rima Paraskumar Pandya et.al. Effect of lumbar stabilization exercises on stable versus unstable surface on pain and function in mechanical low back pain-an evidence based study

22 articles were relevant and from those 17 articles were included in the study (Table 1). Other articles were excluded because it didn't involve population of low back pain and outcome measures were other than pain and function.

Data Analysis: All 17 articles were assessed using 2 scales:

1. The PEDro scale: It assesses methodological quality and consists of a checklist of 11 criteria, 10 of which are scored. For each criterion the study met, 1 point was awarded. The points were tallied and presented as a score out of 10. The scale applies only to experimental studies. For this review, investigations with PEDro scores of 6 to 10 were considered high quality, of 4 to
5 were considered moderate quality, and of 0 to 3 were considered low quality. The PEDro score has demonstrated 'fair' to 'excellent' inter-rater reliability (Intraclass Correlation Coefficient 0.530.91) for randomized controlled trials of physiotherapy interventions. Convergent validity is supported for the PEDro score through correlation with other quality rating scales including: the Jadad scale (0.35) and van Tulder 2003 scale (0.71) for clinical trials of physiotherapy related interventions. ${ }^{[7]}$ (Appendix 1)

\section{The CEBM's Levels of Evidence} scale: It assesses quality based on study design, which categorize the studies in a scale ranging from 1 to 5 with further subdivision for each. (Appendix 2)

Table 1: Characteristics of included studies

\begin{tabular}{|c|c|c|c|c|c|}
\hline $\begin{array}{l}\text { Sr } \\
\text { no. }\end{array}$ & Title & $\begin{array}{l}\text { Study design } \\
\& \text { duration }\end{array}$ & $\begin{array}{l}\text { Articles or } \\
\text { Sample Size }\end{array}$ & $\begin{array}{l}\text { Outcome } \\
\text { Measures }\end{array}$ & $\begin{array}{l}\text { PEDro and Level } \\
\text { of Evidence }\end{array}$ \\
\hline 1 & $\begin{array}{l}\text { Segmental stabilization and muscular } \\
\text { strengthening in chronic low back pain }{ }^{[8]}\end{array}$ & $\begin{array}{l}\text { Comparative study } \\
\text { (6 weeks) }\end{array}$ & 30 & $\begin{array}{l}\text { VAS, } \\
\text { MPQ, } \\
\text { ODI }\end{array}$ & $\begin{array}{l}7 / 10 \\
1 b\end{array}$ \\
\hline 2 & $\begin{array}{l}\text { A Meta-Analysis of Core Stability Exercise } \\
\text { versus General Exercise for Chronic Low Back } \\
\text { Pain }{ }^{[9]}\end{array}$ & A Meta-Analysis & $\begin{array}{c}5 \text { articles } \\
\text { involving } 414 \\
\text { participants }\end{array}$ & - & $1 \mathrm{a}$ \\
\hline 3 & $\begin{array}{l}\text { Effect of Swiss Ball Stabilization Exercise on } \\
\text { Pain and Bone Mineral Density of Patients with } \\
\text { Chronic Low Back Pain }{ }^{[10]}\end{array}$ & $\begin{array}{l}\text { An interventional } \\
\text { study(16 weeks) }\end{array}$ & 36 & $\begin{array}{c}\text { VAS, } \\
\text { DEXTUM T }\end{array}$ & $\begin{array}{l}4 / 10 \\
2 b\end{array}$ \\
\hline 4 & $\begin{array}{l}\text { Effect of Lumbar Stabilization and Dynamic } \\
\text { Lumbar Strengthening Exercises in Patients with } \\
\text { Chronic Low Back Pain }{ }^{[11]}\end{array}$ & $\begin{array}{l}\text { A randomized } \\
\text { controlled trial } \\
(8 \text { weeks })\end{array}$ & 24 & $\begin{array}{l}\text { VAS, } \\
\text { MODI, } \\
\text { Medx }\end{array}$ & $\begin{array}{c}6 / 10 \\
1 b\end{array}$ \\
\hline 5 & $\begin{array}{l}\text { Effect of CORE exercise program on Pain and } \\
\text { Active Range of Motion in patients with Chronic } \\
\text { Low Back Pain }{ }^{[12]}\end{array}$ & $\begin{array}{l}\text { A comparative } \\
\text { study }\end{array}$ & 30 & $\begin{array}{c}\text { VAS } \\
\text { PPA } \\
\text { Goniometer }\end{array}$ & $\begin{array}{c}7 / 10 \\
1 \mathrm{~b}\end{array}$ \\
\hline 6 & $\begin{array}{l}\text { The effect of core stabilization program and } \\
\text { conventional exercise in the management of } \\
\text { people with chronic mechanical low back pain }{ }^{[13]}\end{array}$ & $\begin{array}{l}\text { A randomized } \\
\text { controlled trial } \\
(6 \text { weeks })\end{array}$ & 40 & $\begin{array}{c}\text { VAS, } \\
\text { RMQ, } \\
\text { Goniometer }\end{array}$ & $\begin{array}{c}7 / 10 \\
1 b\end{array}$ \\
\hline 7 & $\begin{array}{l}\text { Core strength training for patients with chronic } \\
\text { low back pain }{ }^{[14]}\end{array}$ & A systematic review & $\begin{array}{c}4 \text { studies } \\
\text { including } 173 \\
\text { subjects }\end{array}$ & - & $1 \mathrm{a}$ \\
\hline 8 & $\begin{array}{l}\text { Effectiveness of core stabilization exercise and } \\
\text { motor control exercise in patients with low back } \\
\text { ache. }{ }^{[15]}\end{array}$ & $\begin{array}{l}\text { Comparative } \\
\text { experimental study } \\
(2 \text { weeks })\end{array}$ & 30 & $\begin{array}{l}\text { VAS, } \\
\text { ODI }\end{array}$ & $\begin{array}{c}7 / 10 \\
1 \mathrm{~b}\end{array}$ \\
\hline 9 & $\begin{array}{l}\text { Effectiveness of the core stabilization exercise on } \\
\text { floor and Swiss ball on individual with non- } \\
\text { Specific low back pain }{ }^{[16]}\end{array}$ & $\begin{array}{l}\text { Experimental study } \\
\quad(4 \text { weeks })\end{array}$ & 30 & $\begin{array}{l}\text { VAS } \\
\text { ODI }\end{array}$ & $\begin{array}{c}7 / 10 \\
1 \mathrm{~b}\end{array}$ \\
\hline 10 & $\begin{array}{l}\text { Effectiveness of core stabilization exercises and } \\
\text { routine exercise therapy in management of pain in } \\
\text { chronic nonspecific low back pain. }{ }^{[17]}\end{array}$ & $\begin{array}{l}\text { A single blinded } \\
\text { randomized } \\
\text { controlled trial } \\
(6 \text { weeks })\end{array}$ & 120 & VAS & $\begin{array}{c}6 / 10 \\
1 b\end{array}$ \\
\hline 11 & $\begin{array}{l}\text { Effect of 6-week Lumbar stabilization exercise } \\
\text { performed on stable versus unstable surface in } \\
\text { automobile assembly workers with mechanical } \\
\text { chronic low back pain. }{ }^{[18]}\end{array}$ & $\begin{array}{l}\text { A randomized } \\
\text { controlled trial } \\
(6 \text { weeks })\end{array}$ & 24 & $\begin{array}{c}\text { VAS, ODI, } \\
\text { BDI, Back } \\
\text { muscle } \\
\text { strength, stork } \\
\text { balance test }\end{array}$ & $\begin{array}{c}4 / 10 \\
2 b\end{array}$ \\
\hline 12 & $\begin{array}{l}\text { Comparative effectiveness of lumbar } \\
\text { stabilization, dynamic strengthening, and Pilates } \\
\text { on chronic low back pain }{ }^{[19]}\end{array}$ & $\begin{array}{l}\text { A randomized } \\
\text { controlled trial } \\
(3 \text { weeks })\end{array}$ & 44 & $\begin{array}{l}\text { VAS, PBU, } \\
\text { MODI, } \\
\text { Modified } \\
\text { schober's test }\end{array}$ & $\begin{array}{c}6 / 10 \\
1 b\end{array}$ \\
\hline 13 & $\begin{array}{l}\text { Core Strengthening For Chronic Nonspecific Low } \\
\text { Back Pain [20] }\end{array}$ & $\begin{array}{l}\text { A Systematic } \\
\text { Review }\end{array}$ & 34 subjects & - & $1 \mathrm{a}$ \\
\hline
\end{tabular}


Rima Paraskumar Pandya et.al. Effect of lumbar stabilization exercises on stable versus unstable surface on pain and function in mechanical low back pain-an evidence based study

\begin{tabular}{|c|c|c|c|c|c|}
\hline \multicolumn{6}{|c|}{ Table no.1 continued..... } \\
\hline 14 & $\begin{array}{l}\text { The effect of lumbar stabilization and walking } \\
\text { exercises on chronic low back pain }{ }^{[21]}\end{array}$ & $\begin{array}{l}\text { A randomized } \\
\text { controlled trial } \\
(6 \text { weeks })\end{array}$ & 48 & VAS & $\begin{array}{c}5 / 10 \\
2 b\end{array}$ \\
\hline 15 & $\begin{array}{l}\text { Effects of Lumbar Stabilization Exercise on a } \\
\text { Swiss ball in Patients with Mechanical Low Back } \\
\text { Pain }{ }^{[22]}\end{array}$ & $\begin{array}{l}\text { An experimental } \\
\text { study } \\
(2 \text { weeks })\end{array}$ & 40 & $\begin{array}{l}\text { NPRS, } \\
\text { RMQ }\end{array}$ & $\begin{array}{c}5 / 10 \\
2 b\end{array}$ \\
\hline 16 & $\begin{array}{l}\text { Comparative Study of Motor Control Exercise } \\
\text { and Global Core Stabilization Exercise on Pain, } \\
\text { Rom and Function in Subjects with Chronic Non- } \\
\text { Specific Low Back Pain }{ }^{[23]}\end{array}$ & $\begin{array}{l}\text { A randomized } \\
\text { controlled trial } \\
\quad(4 \text { weeks })\end{array}$ & 32 & $\begin{array}{l}\text { NPRS, } \\
\text { ODI, } \\
\text { MODIFIED } \\
\text { SCHOBER'S } \\
\text { TEST }\end{array}$ & $\begin{array}{c}6 / 10 \\
1 b\end{array}$ \\
\hline 17 & $\begin{array}{l}\text { Effectiveness of Core Stability and } \\
\text { Diaphragmatic Breathing V/S Core Stability } \\
\text { Alone on Pain and Function in Mechanical Non- } \\
\text { Specific Low Back Pain Patients. }{ }^{24]}\end{array}$ & $\begin{array}{l}\text { A randomized } \\
\text { controlled trial } \\
\quad(4 \text { weeks })\end{array}$ & 46 & $\begin{array}{l}\text { VAS, } \\
\text { ODI, } \\
\text { PBU }\end{array}$ & $\begin{array}{c}6 / 10 \\
1 \mathrm{~b}\end{array}$ \\
\hline
\end{tabular}

\section{RESULTS}

Evidences were reviewed and analysis was done on the basis of PEDro score and CEBM's Level of Evidence Scale.

Total 202 articles were found, out of which 22 articles were relevant and from those 17 articles were included in this evidence-based study and other articles were excluded as per eligibility criteria.

From total 17 studies, there are 1 meta-analysis and 2 systematic reviews and their level of evidence was 1a. 8 out of 17 studies (7 Randomized controlled trials, 2 Comparative studies, 2 Experimental studies, 1 Interventional study) were shown that core stability exercise was effective treatment for reducing pain and improving disability in patients with mechanical or non-specific low back pain when compared to general (conservative) treatment and when combined with other exercises. Their Level of evidence was $1 \mathrm{a}, 1 \mathrm{~b}$ and $2 \mathrm{~b}$.

2 out of 17 (1 Randomized Controlled Trial and 1 comparative study) studies were compared core stability exercise and motor control exercises, their results showed that motor control exercise was more effective than core stability exercise in non-specific low back pain. Both have Level of evidence 1b. 4 out of 17 studies were compared lumbar stabilization exercises on stable versus unstable surface. Their results showed that shown that lumbar stabilization exercise performed on unstable surfaces showed significant improvement in back pain and disability. Their Level of evidence was $1 b$ and $2 b$.

\section{DISCUSSION}

Total 17 studies were included in this evidence-based study. The methodological qualities of included studies were low to high. The sample size varied from 24-414 subjects.

There are 3 strong evidences (metaanalysis and systematic review) which suggest that core stabilization exercise is an effective treatment for reducing pain and disability in patients with mechanical or non-specific low back pain. However, the effects were only short-term.

There are 9 moderate to high quality of evidences which suggest that core stability exercise alone or can be adjunct to other conventional treatment provide significant benefits in reducing pain and dysfunctions in patients with low back pain. Effect by which lumbar stabilization exercises reduces pain and improve function is, it decreases the stimulus delivered to pain sensitive tissues (ligaments and joint capsules) by reducing he load on the lumbar vertebra. It increases the stabilizer muscle function and by this it can contribute to the spinal stability and decrease in pain. ${ }^{[22]}$

Furthermore, there are 3 low to moderate quality of evidences having small sample size which compares lumbar stabilization exercises on stable and unstable surface and their results confirms that lumbar stabilization exercise performed on unstable surface was effective in reducing pain and disability within a short period of time in patients with mechanical low back pain. Total study duration varied from 2 to 16 weeks. Lumbar stabilization exercises if performed on unstable surface 
increase activation and facilitation of spinal stabilizers. By simultaneously activating of global and local muscles at the beginning, exercise on unstable surface may provide stability to the spine and produces more muscle activation than stable surface. Exercise on unstable surface mainly activates local stabilizers of the spine. ${ }^{[22]}$ Paul Marshall et al. In 2005, did the prospective comparison study on "core stability exercise on and off swiss ball" on 8 healthy subjects with intervention of 4 exercise: inclined press-up, upper body rollout, single-leg hold, and quadruped exercise. Result of this study showed that performance of this task on swiss ball led to greater improvement in activation levels as confirmed by surface electromyography. ${ }^{[25]}$ I.R. Scott et al. conducted a cross-sectional case control study in 2015 using rehabilitative ultrasound and concluded that cross sectional area of lumbar multifidus increased when sitting on swiss ball compared to firm surface in both normal individuals and chronic low back pain patients. $^{[26]}$

2 studies which shows that when compared to motor control exercise, there are moderate quality of evidences that confirms that motor control exercise is slightly superior to core stability exercise for improving pain and disability in patients with non-specific low back pain. Reason may be because of plastic changes in the brain due to isolated muscle exercise and changes in trunk muscle behaviour in functional task.

It should be noted that no studies reported adverse effects from core stability exercises performed in general or performed on unstable surface and no any single study used fixed protocol for lumbar stabilization exercise program.

\section{CONCLUSION}

Based on evidences taken from search engines like Google Scholar, Pubmed, Pedro, Science Direct, Research Gate and CINAHL of the year 2010february 2020, it can be concluded that lumbar stabilization exercise performed on unstable surface provide significant benefit in reducing pain and disability within a short period of time in patients with mechanical low back pain.

Conflict of interest: There is no conflict of interest.

\section{ABBREVIATIONS}

LBP: Low Back Pain, PEDro: Physiotherapy

Evidence Database, CEBM: Center of Evidence Based Medicine, CINAHL: Cumulative Index of Nursing and Allied Health Literature, RCT: Randomized Controlled Trial, VAS: Visual Analogue Scale, ODI: Oswestry Disability Index, MODI: Modified Oswestry Disability Index, NPRS: Numeric Pain Rating Scale, PBU: Pressure Biofeedback, RMQ: Ronald Morris Questionnaire, PPA: Pain Pressure Algometer, BDI: Back Depression Inventory, MPQ: McGill Pain Questionnaire, PRISMA: Preferred Reporting Items for systematic reviews and meta-analysis.

\section{Acknowledgement: None}

Source of Funding: None

Ethical Approval: Ethical approval was not required.

\section{REFERENCES}

1. Burton AK. European guidelines for prevention in low back pain, November, 2004.

2. Balague, Federico, et al. The Lancet. "Non-specific low back pain." 2012.

3. Waddell G.: Low back pain: A twentieth century healthcare enigma, Spine, 1996.

4. T. Barza, M. Melloh et al. A conceptual model of compensation/decompensation in lumbar segmental instability. Medical Hypotheses. September 2014.

5. Panjabi MM. The stabilizing system of the spine. Part II. Neutral zone and instability hypothesis. J Spinal Dis. 1992.

6. B Rackwitz et al.; Practicability of segmental stabilizing exercises in the context of a group program for the secondary prevention of low back pain. 
An explorative pilot study. Eura Medicophys. 2007 Sep;43(3):359-67.

7. Aidan Cashin, James $\mathrm{H}$ Mcauley. Clinimetrics: Physiotherapy Evidence Database (PEDro) scale, Journal of physiotherapy, September 2019.

8. Rajan Balakrishnan et al., The Effectiveness of the core stabilisation exercise on floor and Swiss ball on individual with non-Specific low back pain. IJPESH. 2016; 3(1); 347-356.

9. Thomas et al. Segmental stabilization and muscular strengthening in chronic low back pain, CLINICS-2010.

10. Xue-Qiang et al. A meta-analysis of core stability exercise versus general exercise for chronic low back pain, PLOS ONE, 2012.

11. Joo Soo Yoon et al. Effect of Swiss Ball Stabilization Exercise on Pain and Bone Mineral Density of Patients with Chronic Low Back Pain, Journal of physical therapy science, 2013.

12. Moon $\mathrm{H}$ et al. Effect of lumbar stabilization and dynamic lumbar strengthening exercise in patients with chronic low back pain, Annals of rehabilitation medicine, 2013.

13. Hwi-Young et al. Effect of core exercise program on pain and active range of motion in patients with chronic low back pain, Journal of Physical therapy sciene, 2014

14. Suresh et al. The effect of core stabilization program and conventional exercise in the management of people with chronic mechanical low back pain, International Journal of Physiotherapy, 2015

15. Wen-Dien Chang et al. Core strength training for patients with chronic low back pain, Journal of physical therapy science, 2015.

16. Vikranth G.R.et al Effectiveness of core stabilization exercise and motor control exercise in patients with low back ache, International Journal of Physiotherapy, 2015.

17. Muhammed Waseem et al. Effectiveness of core stabilization exercise and routine exercise therapy in management of pain in chronic nonspecific low back pain, Pakistan journal of medical science, 2017.

18. Tae-Woo et al., Effect of 6-week Lumbar Stabilization exercise performed on stable versus unstable surface in automobile assembly workers with mechanical chronic low back pain, IOS press, 2018.

19. Esha A. Bhaduria et al. Comparative effectiveness of lumbar stabilization, dynamic strengthening and pilates on chronic low back pain, Journal of exercise rehabilitation, 2017.

20. Mahmoud ahmed et al. Core strengthening for chronic nonspecific low back pain, Bioscience research,2018

21. Jee Hyun Suhet et al. The effect of lumbar stabilization and walking exercise on chronic low back pain, Medicine, 2019.

22. Alisha Murtaza khokhawala et al, Effects of Lumbar Stabilization Exercise on Swiss ball Patients with Mechanical Low Back Pain, International journal of physiotherapy, 2019.

23. Jayanta Chakraborty et al. Comparative study of motor control exercise and global core stabilization exercise on pain, ROM and function in subjects with chronic nonspecific low back pain, International journal of health science and research, 2019.

24. Shruti Shah et al. Effectiveness of Core Stability and Diaphragmatic Breathing V/S Core stability Exercise alone on Pain and Function in Mechanical Non-Specific Low Back Pain patients: A Randomized Controlled Trial, International Journal of Health Science and Research, 2020.

25. Marshall PW, Murphy BA. Core stability exercises on and off swiss ball. Archives of Physical Medicine and Rehabilitation, 2005.

26. I.R. Scott et al. Swiss ball enhances lumbar multifidus activity in chronic low back pain, Physical Therapy in sport, 2015.

How to cite this article: Pandya RP, Shukla YU. Effect of lumbar stabilization exercises on stable versus unstable surface on pain and function in mechanical low back pain-an evidence based study. International Journal of Science \& Healthcare Research. 2021; 6(2): 273-279. DOI: https://doi.org/10.52403/ijshr. 20210448 
Rima Paraskumar Pandya et.al. Effect of lumbar stabilization exercises on stable versus unstable surface on pain and function in mechanical low back pain-an evidence based study

APPENDIX 1-PEDro SCALE

\begin{tabular}{|l|l|c|}
\hline No. & Description & Yes / No \\
\hline 1 & Eligibility criteria were specified (No points awarded) & \\
\hline 2 & Subjects were randomly allocated to groups & \\
\hline 3 & Allocation was concealed & \\
\hline 4 & The groups were similar at baseline regarding the most important prognostic indicators & \\
\hline 5 & There was blinding of all subjects & \\
\hline 6 & There was blinding of all therapists who administered the therapy & \\
\hline 7 & There was blinding of all assessors who measured at least one key outcome & \\
\hline 8 & Measure of at least one key outcome were obtained from more than 85\% of the subjects initially allocated to groups & \\
\hline 9 & All subjects for whom outcome measures were available received the treatment or control condition as allocated & \\
\hline 10 & The result of between group comparisons are reported for at least one key outcome & \\
\hline 11 & The study provides both point measures and measures of variability for at least one key outcome & \\
\hline
\end{tabular}

APPENDIX 2- CEBM'S LEVEL OF EVIDENCE

\begin{tabular}{|l|l|}
\hline Level & Definition \\
\hline 1a & Systematic reviews of randomized controlled trials \\
\hline 1b & Individual randomized controlled trials \\
\hline 1c & All-or-none studies \\
\hline 2a & Systematic reviews of cohort studies \\
\hline 2b & Individual cohort studies or low-quality randomized controlled trials \\
\hline 2c & Outcome research \\
\hline $3 a$ & Systematic reviews of case-control studies \\
\hline $3 b$ & Individual case-control studies \\
\hline 4 & Case series, poorly designed cohort or case-control studies \\
\hline 5 & Animal and bench research, expert opinion \\
\hline
\end{tabular}

$* * * * * *$ 